Article

\title{
Deriving Major Fire Risk Evaluation Items Utilizing Spatial Information Convergence Technology in Dense Areas of Small Obsolete Buildings
}

\author{
Hyung-Joo Lee ${ }^{1}$, Sun-Woo Park ${ }^{2}$, Seungjun Roh ${ }^{3, *} \mathbb{1}$, Jung-Rim Ryu ${ }^{4,5, *}$, Byeung-Hun Son ${ }^{6}$, Seong-Ryong Ryu ${ }^{3}$, \\ Seung-youp Lee ${ }^{3}$ and Won-Jun Park ${ }^{7}$ (i) \\ 1 Department of Urban and Environmental Engineering, Ulsan National Institute of Science and Technology, \\ Ulsan 44919, Korea; hyungjoolee@unist.ac.kr \\ 2 Department of Architectural Engineering, Kumoh National Institute of Technology, Gumi 39177, Korea; \\ psw0911@kumoh.ac.kr \\ 3 School of Architecture, Kumoh National Institute of Technology, Gumi 39177, Korea; \\ archiryu@kumoh.ac.kr (S.-R.R.); syobi@kumoh.ac.kr (S.-y.L.) \\ 4 FMworks Inc., Daegu 41542, Korea \\ 5 School of Architecture, Kyungpook National University, Daegu 41566, Korea \\ 6 Department of Architecture, Daegu Technical University, Daegu 42734, Korea; sonbh@ttc.ac.kr \\ 7 Department of Architectural Engineering, Kangwon National University, Samcheok 25913, Korea; \\ wjpark@kangwon.ac.kr \\ * Correspondence: roh@kumoh.ac.kr (S.R.); ajaxrim@gmail.com (J.-R.R.); \\ Tel.: +82-54-478-7595 (S.R.); +82-53-955-2550 (J.-R.R.)
}

check for
updates

Citation: Lee, H.-J.; Park, S.-W.; Roh, S.; Ryu, J.-R.; Son, B.-H.; Ryu, S.-R.; Lee, S.-y.; Park, W.-J. Deriving Major Fire Risk Evaluation Items Utilizing Spatial Information Convergence Technology in Dense Areas of Small Obsolete Buildings. Sustainability 2021, 13, 12593. https://doi.org/ $10.3390 /$ su132212593

Academic Editors: Paulo Santos and Sunkuk Kim

Received: 16 August 2021

Accepted: 9 November 2021

Published: 15 November 2021

Publisher's Note: MDPI stays neutral with regard to jurisdictional claims in published maps and institutional affiliations.

Copyright: () 2021 by the authors. Licensee MDPI, Basel, Switzerland. This article is an open access article distributed under the terms and conditions of the Creative Commons Attribution (CC BY) license (https:// creativecommons.org/licenses/by/ $4.0 /)$.
Abstract: As small obsolete buildings are exposed to high fire risks, governments are trying to evaluate their fire risks and preferentially improve fire protection performance for high risk buildings, however, the evaluation manpower and time are insufficient compared to the rapidly increasing number of obsolete buildings. Therefore, this study aimed to derive major fire risk index (FRI) evaluation items as part of developing a platform to quickly and efficiently evaluate fire risks in dense areas of small obsolete buildings utilizing spatial information convergence technology. To this end, 20 preliminary evaluation items specifically tailored to dense areas of small obsolete buildings were derived through a field survey, investigation of FRI evaluation items from existing works, and expert pre-reviews. Based on the derived 20 preliminary items, an importance survey was conducted with a total of 181 fire safety experts including fire officers, university professors, researchers, industry experts, and fire insurers. As a result, a total of 12 major evaluation items (e.g., outdoor fire extinguisher, distance to 119 Safety Center, building structure, building cladding, illegal alterations, illegal parking, and liquefied natural gas cylinder) were derived. Results can help to evaluate the fast and efficient fire risks in dense areas of small obsolete buildings.

Keywords: fire risk; fire risk index; evaluation item; small obsolete building; spatial information convergence technology

\section{Introduction}

Fire is a disaster with devastating consequences on human life and property [1]. According to the 2020 Fire Statistical Yearbook of Korea [2], the annual average number of fire events in Korea for the past 10 years (2011-2020) was 42,332, with 2215 casualties (309 deaths, 1907 injuries) and approximately 415 million dollars of property damage. Among the types of fires, the cases of fire outbreak in residential facilities accounted for the largest proportion (26.3\%) of the total fires, and most of these fire events occurred in small, old buildings that were not equipped with advanced automatic fire extinguishing systems. The small, old buildings did not meet the current fire safety standard requirements as they were built before the application of the tightened fire safety performance standards [3]. 
Additionally, the physical performance of the fire safety devices installed at the time of construction is degraded due to aging. There are also many cases of illegal changes in building use or illegal extensions. In addition, there are a number of cases in which multiple buildings are densely distributed in a certain area, which increases the risk of a fire spreading because illegal parking in the narrow road networks makes it difficult to carry out final suppression activities [4]. In Korea, in particular, the proportion of old buildings, where more than 30 years have elapsed since the first approval for building use, has gradually increased from $36.5 \%$ in 2017 to $37.1 \%$ in 2018 and $37.8 \%$ in 2019 , which underscores the importance of the fire risk management of old buildings [5].

The fire risk in buildings can be managed using the fire risk index (FRI) [6-8]. The FRI refers to the numerical representation of the evaluation results in which potential fire risk, spread, and ease of fire suppression are evaluated in advance from the perspective of a building or building district. Representative examples of FRIs include the U.S. Fire Safety Evaluation System (FSES), FireCast, and the Swiss Fire Risk Evaluation Model (FREM) [9-12]. The stability of all buildings and the risk of fire outbreak and spread are evaluated with these indices in the construction, design, and maintenance phases. The evaluation results are actively utilized in pre-emptive responses for buildings that are vulnerable to fire risk and for the determination of fire insurance premium rates. The U.S. FSES evaluates whether the design meets the standards of the Life Safety Code 101, a building code. It judges the fire safety and risk of a building for containment, extinguishment, and people movement through the worksheet, weighting, and indexing methods, and the results are expressed as pass or fail. FireCast uses big data in various fields to determine the priority of fire risk for all buildings located in New York. This system is actively utilized for structural reinforcement of existing buildings, the pre-emptive responses for buildings that are vulnerable to fire risk, and the establishment of safety inspection plans. Swiss FREM, as a fire risk assessment model for factories and large buildings, evaluates the fire risk and determines the fire insurance premium rates based on the results. This model uses the method of evaluating a fire risk checklist with weights for each item and indexing factor, and the final result is expressed as a grade.

Examples of FRIs in Korea include the Korea Fire Protection Association [4,13-16], the publicly used facilities fire risk assessment of the National Fire Agency $[4,15,16]$, and the Korea Safety Map [17] of the National Disaster Management Research Institute. In the case of Korea, FRI and the publicly used facilities fire risk assessment use more than 30 evaluation items for a detailed evaluation of the fire risk level of buildings. However, these evaluations are conducted through on-site visits and direct manual checking of evaluation items consisting of factors that induce or suppress fire in a building. Although direct evaluation including on-site visits and direct manual checking have the advantage of enabling relatively accurate FRI evaluation, this method has practical limitations in that it requires significant professional manpower and time for its evaluation. In addition, a method using statistical data presenting the types and levels of fire events has a limitation in that it is unable to reflect the current level and status of a building such as illegal changes in building use or illegal parking, even though this method facilitates fast FRI evaluation $[4,15,16]$.

To address these limitations, the adoption of various smart technologies such as the Artificial Intelligence of Things, big data, clouds, drones, and geographic information systems (GIS) have been emphasized in recent years to achieve effective fire prevention and management that accurately reflect the current level and state of buildings [18-23]. This is because smart technology enables fast and effective collection and analysis of a large amount of information on various risk factors. In particular, spatial information convergence technology that links drones and GIS enables advanced visual management of fire risk areas and risk factors. In the event of a fire incident, the technology is capable of analyzing the road conditions, accessing the road status in the impacted area, and evaluating the trajectory analysis of the fire trucks, thus contributing to the improvement in accessibility to the fire site [23-27]. 
Due to these advantages, many researchers are utilizing spatial information convergence technology for evaluating a fire risk, developing a fire risk management platform or map. Masoumi et al. [27] proposed a method of synthesizing the location information of the target site made of unmanned aerial vehicles and attribute information (mainly industry) of each building and producing a two-dimensional fire risk map for urban areas through spatial analysis. Nisanci [28] produced a dynamic fire map using geographical information systems (GIS) and conducted a pilot application for the establishment of a sample fire database based on GIS and as the basis of sample spatial queries in support of fire management for the city center of Trabzon in Turkey. Yagoub and Jalil [29] used GIS technology for mapping 220 sampled fire incidents in Sharjah city, UAE, and proposed new suitable locations for fire stations through measuring the emergency time response of the fire vehicles in the city and weighted overlay analysis. Xiao et al. [30] conducted a GISbased fire risk assessment and fire station site selection for the urban area of Dujiangyan City using ten risk assessment factors selected to include substations, building floor area ratios, and miniature fire stations.

These spatial information convergence technologies and their evaluation items need to secure the suitability of attribute information for its own evaluation target, purpose, and region, and it is important that the evaluation information collected by various methods should be indexed and matched with valid location information [31,32].

Therefore, this study aims to derive major evaluation items to concisely assess the level of fire risk in dense areas of small obsolete buildings and then review a plan to utilize spatial information convergence technology as part of research on the development of a quick and efficient FRI evaluation platform for dense areas of small obsolete buildings.

\section{Materials and Methods}

In order to evaluate the FRI utilizing spatial information convergence technology, the evaluation item should meet its own evaluation target and purpose, and the evaluation information collected by various methods should be indexed and matched with location information. Fire risk evaluation items to be derived in this study should therefore be specifically tailored to dense areas of small obsolete buildings, and inevitably consider the time limitation of the collection of information and minimize site visits as much as possible for rapid evaluation at the building district level.

In the first step of this study, preliminary FRI evaluation items specifically tailored to dense areas of small obsolete buildings were derived through a field survey of a dense area of small obsolete buildings, the investigation of FRI evaluation items from existing works, and expert pre-reviews. In the second step, a survey of evaluation items was conducted with fire safety experts that included fire officers, university professors, researchers, industry experts, and fire insurance practitioners. Then, the specific FRI evaluation items for dense areas of small obsolete buildings were derived, and a plan to utilize spatial information convergence technology was reviewed. Figure 1 shows the overall flow of this study.

\subsection{Derivation of Preliminary Evaluation Items \\ 2.1.1. Field Survey}

To derive the FRI evaluation items of dense areas of small obsolete buildings, it is necessary to examine their characteristics. In this study, we visited a dense area of small obsolete buildings to examine the characteristics and current status of the fire risk factors. The site of the field survey was one of the target sites of a residential environment improvement project located in Jung-gu, Daegu Metropolitan City, Korea. It is a building district in which small, old, and defective buildings account for more than two-thirds of the buildings in the district. This area has a high risk of fire and obstacles to firefighting activities due to the high percentage of unauthorized buildings and high occupancy of roads under $4 \mathrm{~m}$ wide. 


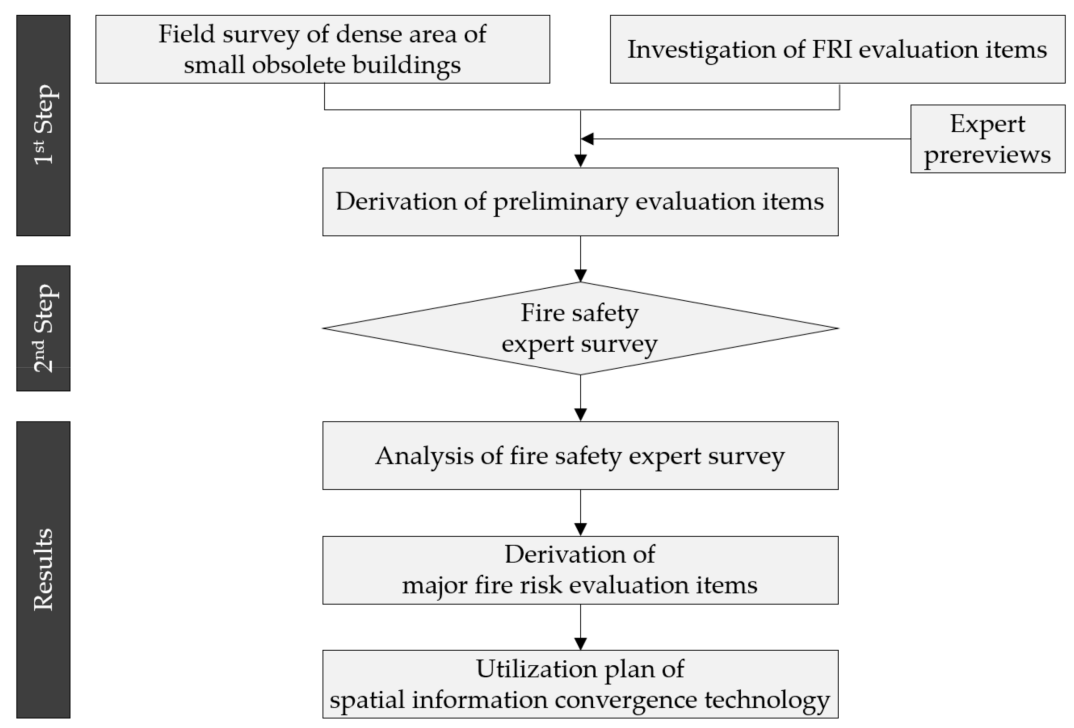

Figure 1. Overall flow of this study.

In the area around the survey site, there were 386 densely populated old residential buildings and neighborhood facilities, illegal alterations using sandwich panels that are vulnerable to fire, exposure of liquefied natural gas (LNG) cylinders with the risk of explosion, illegal parking, and narrow passages that could serve as obstacles to firefighting activities. In addition, outdoor fire extinguishers were placed at various locations in passages in case they were not provided inside each building. The status of the field survey site for the deteriorated building district in this study is shown in Figure 2.
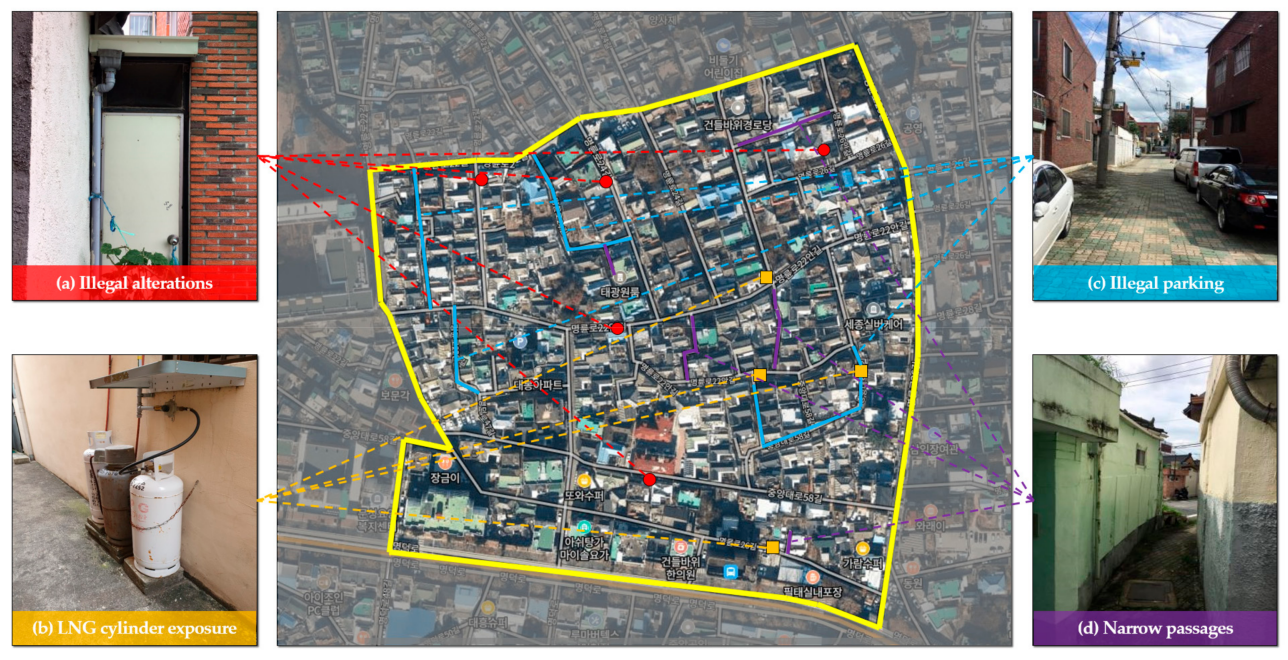

Figure 2. Status of the field survey site in the dense area of small obsolete buildings.

\subsubsection{Investigation of FRI Evaluation Items}

Fire risk assessment has been applied in various methods depending on its purpose by country and region. To investigate the existing fire risk evaluation items, this study examined the U.S. FSES, the Swiss FREM, the Korea FRI, and the publicly used facilities fire risk assessment.

The U.S. FSES is an evaluation system for health care occupancies, detention and correctional occupancies, board and care occupancies, business occupancies, educational occupancies, and evaluates whether the design meets the standards of the Life Safety Code 101, a building code. The main evaluation items consist of structures (1st, 2nd, 3rd, 4th floor, etc.), corridors and evacuation passages, interior materials, corridor walls, a gate 
toward corridors, the size of fire compartments, vertical openings, dangerous zones, smoke venting, emergency routings, manual fire alarm systems, and automatic sprinklers, as shown in Table 1. FSES compares the fire safety levels according to specific life safety standards, and provides technical data on the selection method of the evaluation item, setting quantitative indicators, and weighting for each evaluation item $[4,31]$.

Table 1. Evaluation items of the U.S. Fire Safety Evaluation System.

\begin{tabular}{|c|c|c|c|c|c|c|c|c|}
\hline \multirow{3}{*}{ Category } & \multirow{3}{*}{ Evaluation Items } & \multicolumn{7}{|c|}{ Facilities } \\
\hline & & \multirow[b]{2}{*}{$\mathbf{H}^{1}$} & \multirow[b]{2}{*}{$\mathrm{D}^{2}$} & \multicolumn{3}{|c|}{ B1 ${ }^{3}$} & \multirow[b]{2}{*}{ B2 ${ }^{4}$} & \multirow[b]{2}{*}{$E^{5}$} \\
\hline & & & & $\mathrm{S}^{6}$ & $\mathrm{~L}^{7}$ & $A^{8}$ & & \\
\hline Structure & Construction & 0 & $\bigcirc$ & $\bigcirc$ & $\bigcirc$ & $\bigcirc$ & $\bigcirc$ & O \\
\hline \multirow{4}{*}{$\begin{array}{l}\text { Building } \\
\text { material }\end{array}$} & $\begin{array}{l}\text { Interior finish (Corridor and } \\
\text { exits) }\end{array}$ & $\bigcirc$ & $\bigcirc$ & O & $\bigcirc$ & $\bigcirc$ & $\bigcirc$ & $\bigcirc$ \\
\hline & Interior finish (Rooms) & $\bigcirc$ & - & - & - & - & - & 0 \\
\hline & Interior finish (Lobbies) & - & $\bigcirc$ & - & - & - & - & $\bigcirc$ \\
\hline & Corridor partitions and walls & $\bigcirc$ & - & - & - & - & - & - \\
\hline \multirow{5}{*}{ Space division } & Zone dimensions & O & - & - & - & - & - & - \\
\hline & Separation of residential areas & - & 0 & - & - & - & - & - \\
\hline & Separation of sleeping rooms & - & - & $\bigcirc$ & $\bigcirc$ & - & - & - \\
\hline & $\begin{array}{l}\text { Separation of board and care } \\
\text { home unit and exit route }\end{array}$ & - & - & - & - & $\bigcirc$ & - & - \\
\hline & $\begin{array}{l}\text { Separation of corridor and } \\
\text { rooms }\end{array}$ & - & - & - & - & - & $\bigcirc$ & O \\
\hline \multirow{8}{*}{$\begin{array}{l}\text { Evacuation } \\
\text { facility }\end{array}$} & Doors to corridor & $\bigcirc$ & - & - & - & - & - & - \\
\hline & $\begin{array}{l}\text { Cell and sleeping room } \\
\text { enclosure }\end{array}$ & - & $\bigcirc$ & - & - & - & - & - \\
\hline & Vertical openings & $\bigcirc$ & $\bigcirc$ & - & $\bigcirc$ & $\bigcirc$ & $\bigcirc$ & $\bigcirc$ \\
\hline & Hazardous areas & $\bigcirc$ & $\bigcirc$ & $\bigcirc$ & $\bigcirc$ & O & $\bigcirc$ & 0 \\
\hline & Exit system & - & 0 & - & 0 & 0 & - & - \\
\hline & Exit access & - & 0 & - & $\bigcirc$ & $\bigcirc$ & $\bigcirc$ & $\bigcirc$ \\
\hline & Emergency movement routes & $\bigcirc$ & - & - & - & - & - & - \\
\hline & Means of escape & - & - & 0 & - & - & 0 & 0 \\
\hline \multirow{6}{*}{$\begin{array}{l}\text { Firefighting } \\
\text { facilities }\end{array}$} & Automatic sprinklers & $\bigcirc$ & 0 & $\bigcirc$ & $\bigcirc$ & 0 & $\bigcirc$ & 0 \\
\hline & Smoke control & $\bigcirc$ & $\bigcirc$ & - & $\bigcirc$ & 0 & 0 & $\bigcirc$ \\
\hline & Manual fire alarms & 0 & $\bigcirc$ & $\bigcirc$ & $\bigcirc$ & 0 & O & - \\
\hline & Smoke detection and alarms & 0 & $\bigcirc$ & 0 & 0 & O & $\bigcirc$ & - \\
\hline & $\begin{array}{l}\text { Detection, alarm, and } \\
\text { communications }\end{array}$ & - & - & - & - & - & - & 0 \\
\hline & $\begin{array}{l}\text { Emergency forces } \\
\text { notifications }\end{array}$ & - & - & - & - & - & - & 0 \\
\hline Fire drill & $\begin{array}{l}\text { Occupant emergency } \\
\text { programs }\end{array}$ & - & - & - & - & - & 0 & 0 \\
\hline
\end{tabular}

${ }^{1} \mathrm{H}$ : Health care occupancy; ${ }^{2}$ D: Detention and correctional occupancy; ${ }^{3} \mathrm{~B} 1$ : Board and care occupancy; ${ }^{4} \mathrm{~B} 2$ : Business occupancy; ${ }^{5}$ E: Educational occupancy; ${ }^{6}$ S: Small-scale facility; ${ }^{7}$ L: Large-scale facility; ${ }^{8}$ A: Apartment Building; $\bigcirc$ : Include.

Swiss FREM was proposed by Max Gretener, President of the Swiss Fire Prevention Service (SFPS), and evaluates the quantitative fire risk based on the fire risk factors and fire protection factors $[31,33,34]$. Table 2 shows the evaluation items of the Swiss FREM.

The fire risk factors are composed as the product of potential fire risk and active risk factors. The potential risk factors consist of seven evaluation items including dynamic fire load, combustibility, smoke, corrosion, static fire load, floor level, and surface amplitude. Active risk factors include heat, electric, mechanic, chemical risk, arrangement, maintenance, fire handling, and smoking.

Fire protection factors are calculated as the product of general countermeasure, special countermeasure, and building fireproof. The evaluation items of general countermeasures include portable extinguisher, hydrant, water supply, length of the pipeline, and experienced staff. Special countermeasure factors include fire detection, alert, ability of public fire brigade dispatch, time of fire brigade dispatch, automatic fire detecting system, and 
smoke evacuation system. Building fireproof factors include fireproof structure, facade, compartment, and size of the fireproof chamber.

Table 2. Evaluation items of the Swiss Fire Risk Evaluation Model.

\begin{tabular}{|c|c|c|}
\hline Category & Sub-Category & Evaluation Items \\
\hline \multirow{12}{*}{ Fire risk } & \multirow{7}{*}{ Potential fire risk } & Dynamic fire load \\
\hline & & Combustibility \\
\hline & & Smoke \\
\hline & & Corrosion \\
\hline & & Static fire load \\
\hline & & Floor level \\
\hline & & Surface amplitude \\
\hline & \multirow{5}{*}{ Active risk } & Heat, electric, mechanic, chemical risk \\
\hline & & Arrangement \\
\hline & & Maintenance \\
\hline & & Fire handling \\
\hline & & Smoking \\
\hline \multirow{15}{*}{ Fire protection } & \multirow{5}{*}{ General countermeasure } & Portable extinguisher \\
\hline & & Hydrant \\
\hline & & Water supply \\
\hline & & Length of pipeline \\
\hline & & Experienced staff \\
\hline & \multirow{6}{*}{ Special countermeasure } & Fire detector \\
\hline & & Alert \\
\hline & & Ability of public fire brigade dispatch \\
\hline & & Time of fire brigade dispatch \\
\hline & & Automatic fire detecting system \\
\hline & & Smoke evacuation system \\
\hline & \multirow{4}{*}{ Building fireproof } & Fireproof structure \\
\hline & & Facade \\
\hline & & Compartment \\
\hline & & Size of fireproof chamber \\
\hline
\end{tabular}

Korea FRI evaluates large buildings such as department stores, retail stores, hotels, lodging establishments, mixed-use buildings, and apartments, and estimates the fire risk evaluation grade as a ratio based on the countermeasure and risk scores as shown in Table 3. The main FRI risk factor evaluation items were the number of floors, structure, size, fire load, fire facilities, gas facilities, hazardous materials facilities, and electric facilities. The main evaluation items for countermeasures were fire extinguishers, fire hydrant facilities, emergency alarms, broadcasting systems, firestop systems, evacuation facilities, and smokecontrol systems [4,13-16].

The targets of the Korea publicly used facilities fire risk assessment include cases in which more than 50 publicly used facilities are concentrated within a $2000 \mathrm{~m}^{2}$ area, or when more than 10 publicly used facilities are included in a building with five or more stories. The fire risk level for publicly used facilities fire risk assessment was determined by using a risk level matrix that applied the fire intensity and fire probability indices, as shown in Figure 3. 
Table 3. FRI evaluation items of the Korea Fire Protection Association.

\begin{tabular}{|c|c|c|}
\hline Category & Sub-Category & Evaluation Items \\
\hline \multirow{3}{*}{ Fire risk } & Basic risk & $\begin{array}{l}\text { Number of floors } \\
\text { Structure } \\
\text { Building size } \\
\text { Multi-use risk } \\
\text { Mobility discomfort risk } \\
\text { Accommodation risk } \\
\text { Fire load }\end{array}$ \\
\hline & Ignition risk & $\begin{array}{l}\text { Fire facilities } \\
\text { Gas facilities } \\
\text { Hazardous materials facilities } \\
\text { Electric facilities }\end{array}$ \\
\hline & Process risk & $\begin{array}{l}\text { Process basic risk } \\
\text { Use of dangerous material } \\
\text { Firearm work in the process } \\
\text { Combustible gas use/generation } \\
\text { High temperature and high pressure } \\
\text { Static electricity } \\
\text { Dust } \\
\text { High voltage }\end{array}$ \\
\hline \multirow{6}{*}{ Countermeasure } & Building management & - \\
\hline & $\begin{array}{l}\text { Fire extinguishing } \\
\text { equipment }\end{array}$ & $\begin{array}{l}\text { Fire extinguishers } \\
\text { Indoor fire hydrant facilities } \\
\text { Outdoor fire hydrant facilities } \\
\text { Sprinkler equipment } \\
\text { Gas-based fire extinguishing system }\end{array}$ \\
\hline & Alarm facility & $\begin{array}{l}\text { Automatic fire detection facility } \\
\text { Emergency alarms } \\
\text { Broadcasting systems }\end{array}$ \\
\hline & $\begin{array}{l}\text { Passive fire protection } \\
\text { system }\end{array}$ & $\begin{array}{l}\text { Firestop systems } \\
\text { Evacuation facilities }\end{array}$ \\
\hline & $\begin{array}{l}\text { Fire extinguishing } \\
\text { equipment }\end{array}$ & $\begin{array}{l}\text { Smoke-control systems } \\
\text { Other fire extinguishing equipment }\end{array}$ \\
\hline & Public fire brigade & - \\
\hline
\end{tabular}

The fire intensity index was categorized into building safety, evacuation capacity, and fire characteristics scores, as shown in Table 4. The main evaluation items related to the building safety score included the building structure, floor area ratio, type of building interior materials, sprinkler installation status, firestop systems, and facilities. The main evaluation items related to the evacuation capacity score included the number of evacuation floors, width and walking distance of corridors, rooftop plaza, smoke-control system, evacuation mechanism, and lifesaving mechanisms. The main evaluation items related to the fire characteristics score included the type of fire extinguisher placement, presence of a fire hydrant or sprinklers, emergency response organization, regular inspection, and fire safety training $[4,13-16]$. 

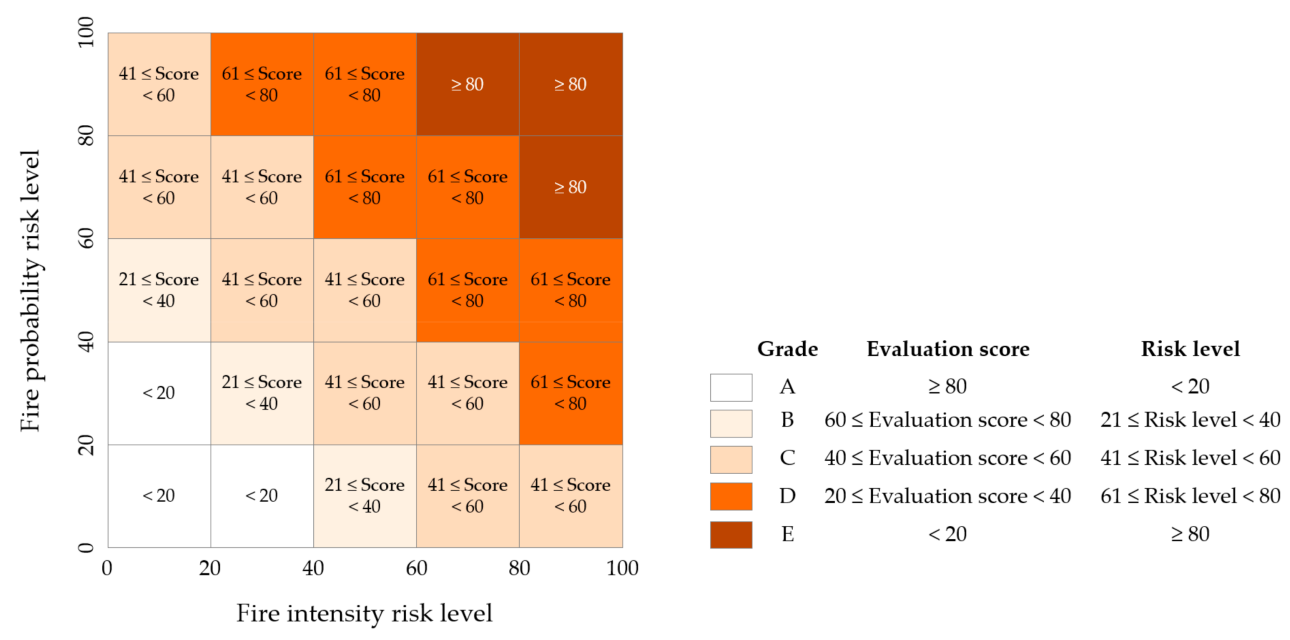

Figure 3. Fire risk level assessment matrix.

Table 4. Fire intensity evaluation items of the Korea publicly used facilities fire risk assessment.

\begin{tabular}{|c|c|c|}
\hline Category & Sub-Category & Evaluation Items \\
\hline $\begin{array}{l}\text { Building } \\
\text { safety }\end{array}$ & - & $\begin{array}{l}\text { Building structure } \\
\text { Floor area ratio } \\
\text { Type of building interior materials } \\
\text { Interior decoration } \\
\text { Firestop systems and facilities } \\
\text { Boundary walls and partition walls } \\
\text { Buildings in the firefighting district } \\
\text { Fire prevention facility maintenance }\end{array}$ \\
\hline \multirow{3}{*}{$\begin{array}{l}\text { Evacuation } \\
\text { capacity }\end{array}$} & $\begin{array}{l}\text { Building } \\
\text { Evacuation } \\
\text { capacity }\end{array}$ & $\begin{array}{l}\text { Number of evacuation floors } \\
\text { Width and quantities of directly emergency stair } \\
\text { Width of corridors } \\
\text { Walking distance of corridors } \\
\text { Exit to the outside of the building } \\
\text { Rooftop plaza } \\
\text { Smoke-control system }\end{array}$ \\
\hline & $\begin{array}{l}\text { Business } \\
\text { Evacuation } \\
\text { capacity }\end{array}$ & $\begin{array}{l}\text { Business exit evacuation capacity } \\
\text { Form of escape route } \\
\text { Bending of internal passages of business sites } \\
\text { Width of the hallway inside the business } \\
\text { Walking distance to the exit of the business } \\
\text { Evacuation map and video }\end{array}$ \\
\hline & $\begin{array}{l}\text { Evacuation } \\
\text { facilities }\end{array}$ & $\begin{array}{l}\text { Evacuation mechanism } \\
\text { Lifesaving mechanism } \\
\text { Emergency light } \\
\text { Guidance light } \\
\text { Portable emergency light }\end{array}$ \\
\hline \multirow[t]{2}{*}{$\begin{array}{l}\text { Fire } \\
\text { characteristics }\end{array}$} & $\begin{array}{l}\text { Fire safety } \\
\text { characteristics }\end{array}$ & $\begin{array}{l}\text { Type of fire extinguisher placement } \\
\text { Presence of a fire hydrant } \\
\text { Sprinkler installation } \\
\text { Emergency response organization } \\
\text { Regular inspection } \\
\text { Fire safety training }\end{array}$ \\
\hline & $\begin{array}{l}\text { Potential risk } \\
\text { characteristics }\end{array}$ & $\begin{array}{l}\text { Location and protective ability of potential danger } \\
\text { Potential risk criteria: flashover occurrence }\end{array}$ \\
\hline
\end{tabular}




\subsubsection{Derivation of Preliminary Evaluation Items}

The results of a field survey for a dense area of small obsolete buildings and detailed evaluation items of the existing FRI evaluation system were collated with the pre-review opinions of fire safety experts belonging to the Korea National Fire Service Academy (KNFA) and derived a total of 20 FRI preliminary evaluation items specifically tailored to dense areas of small obsolete buildings, as shown in Table 5. These items were reflected not only in the basic factors of the existing FRI evaluation such as fire extinguisher, fire hydrant, sprinkler, structure and size of the building, but also illegal alterations, illegal parking, outdated electrical equipment, and LNG cylinders derived in this study from a field survey of the dense area of small obsolete buildings.

Table 5. FRI preliminary evaluation items.

\begin{tabular}{|c|c|c|}
\hline Category & Preliminary Evaluation Items & Description \\
\hline \multirow{7}{*}{$\begin{array}{l}\text { Fire } \\
\text { extinguishing } \\
\text { facilities }\end{array}$} & (1) Outdoor fire extinguisher & $\begin{array}{l}\text { Whether equipped with an outdoor fire } \\
\text { extinguisher within the effective radius }\end{array}$ \\
\hline & (2) Outdoor fire hydrant & Whether equipped with an outdoor fire \\
\hline & (3) Fire detection system & $\begin{array}{l}\text { Compliance status with the automatic fire } \\
\text { detection system installation standards }\end{array}$ \\
\hline & (4) Sprinkler & $\begin{array}{l}\text { Compliance status with sprinkler installation } \\
\text { standards }\end{array}$ \\
\hline & (5) Size of the 119 Safety Center & $\begin{array}{l}\text { Size of the adjacent } 119 \text { Safety Center (e.g., } \\
\text { fire trucks, fire officers) }\end{array}$ \\
\hline & (6) Distance to 119 Safety Center & $\begin{array}{l}\text { Distance between the building and } 119 \text { Safety } \\
\text { Center }\end{array}$ \\
\hline & (7) Distance to A\&E & $\begin{array}{l}\text { Distance between the building and A\&E in } \\
\text { the vicinity }\end{array}$ \\
\hline \multirow{8}{*}{$\begin{array}{l}\text { Construction } \\
\text { information }\end{array}$} & (1) Year of completion & $\begin{array}{l}\text { Year of completion to reflect the aging level } \\
\text { of the building }\end{array}$ \\
\hline & (2) Building structure & $\begin{array}{l}\text { Building structure such as reinforced } \\
\text { concrete or masonry }\end{array}$ \\
\hline & (3) Principal use of building & $\begin{array}{l}\text { Principal use of building, such as housing } \\
\text { and neighborhood facilities }\end{array}$ \\
\hline & (4) Number of upper ground levels & $\begin{array}{l}\text { Number of upper ground levels in the } \\
\text { building (reflection of building dimension) }\end{array}$ \\
\hline & (5) Number of lower ground levels & $\begin{array}{l}\text { Number of lower ground levels in the } \\
\text { building (reflection of building dimension) }\end{array}$ \\
\hline & (6) Gross floor area of building & $\begin{array}{l}\text { Gross floor area of building to reflect the } \\
\text { building dimension }\end{array}$ \\
\hline & (7) Type of building cladding & $\begin{array}{l}\text { Flame-retardant performance of the main } \\
\text { finishing material for exterior walls of the } \\
\text { building }\end{array}$ \\
\hline & $\begin{array}{l}\text { (8) Number of regular building } \\
\text { occupants }\end{array}$ & $\begin{array}{l}\text { Number of regular building occupants, such } \\
\text { as residents or workers in the building }\end{array}$ \\
\hline \multirow{5}{*}{ Risk factors } & (1) History of fire incidents & History of fire incidents in the building \\
\hline & (2) Illegal alterations & $\begin{array}{l}\text { Status of alterations of the building such as } \\
\text { an illegal extension }\end{array}$ \\
\hline & (3) Illegal parking & $\begin{array}{l}\text { Status of day/night illegal parking } \\
\text { interfering with fire truck entry }\end{array}$ \\
\hline & (4) Electrical equipment & $\begin{array}{l}\text { Status of changes in the risks of old poles and } \\
\text { electrical equipment }\end{array}$ \\
\hline & (5) LNG cylinder & $\begin{array}{l}\text { Status of installation and use of LNG } \\
\text { cylinders outside the building }\end{array}$ \\
\hline
\end{tabular}

In addition, the derived preliminary evaluation items were classified into fire extinguishing facilities, construction information, and risk factors according to their characteristics. Fire extinguishing facilities are for suppressions and responsive actions to fire. Namely, when a fire occurs in a building, fire extinguishing facilities are an element that detects the fire immediately, prevents the spread of fire, limits the scale of damage, and is an element used for firefighting activities by the fire brigade. In this study, outdoor fire extinguishers, outdoor fire hydrants, fire detection systems, sprinklers, the scale and distance to the adjacent 119 Safety Center, and accident and emergency (A\&E) department were derived as preliminary items of fire extinguishing facilities. Construction information refers to the basic information of the small obsolete buildings including preliminary items such as the year of completion, building structure, primary use, number of upper and lower ground levels, gross floor area, type of building cladding, and number of regular building occupants. Preliminary items included in construction information are factors to 
reflect the unique conditions and characteristics of the small obsolete building, and in some cases, each item might reduce or aggravate the risk and damage of the fire. The risk factors indicate the factors posing as threats in terms of causing a fire or aggravating the risk and damage when a fire occurs including preliminary items such as the history of fire incidents, illegal alterations, illegal parking, electrical equipment, and exposure to LNG cylinders.

\subsection{Fire Safety Expert Survey}

The opinions of fire safety experts from various occupations were needed for the FRI evaluation of buildings and to determine the importance of the evaluation items. Therefore, a survey was conducted with fire safety experts to judge the importance of the 20 FRI preliminary evaluation items affecting the occurrence of fire and the spread of damage in order to derive specialized FRI evaluation items for dense areas of small obsolete buildings. For each item, the judges chose Strongly Agree, Agree, Average, Disagree, or Strongly Disagree according to the Likert scale, which were valued at 5, 4, 3, 2, and 1 points, respectively. Based on the scores for each evaluation item surveyed in this study, the average, standard deviation, variance, confidence interval of the $95 \%$ confidence level, and Cronbach's alpha coefficient were analyzed. Cronbach's alpha tests are an estimated reliability index based on the internal consistency of the questions and are mainly used to estimate the reliability of the multiple-question Likert scale surveys. This considers each question as a test and calculates how consistently the respondents respond to the questions as a coefficient $(\alpha)$, and it can be judged if $0.5>\alpha$ is unacceptable, $0.5 \leq \alpha<0.6$ is poor, $0.6 \leq \alpha<0.7$ is questionable, $0.7 \leq \alpha<0.8$ is acceptable, $0.8 \leq \alpha<0.9$ is good, and $0.9 \leq \alpha$ is excellent.

A total of 181 fire-safety experts participated in the survey as shown in Table 6. Classified by occupation, there were 125 fire officers, four university professors majoring in firefighting and disaster prevention, 17 researchers from research institutes related to firefighting, 19 members from the Korea Fire Safety Institute (KFSI)/Korea Disaster Prevention Association (KFDA), 12 industry experts in charge of designing fire extinguishing facilities, and four staff from fire insurance companies. Among them, 118 experts with more than 10 years of work experience accounted for about $65 \%$ of the total number of experts. The survey was conducted using face-to-face and remote methods, considering the schedule of the experts and the special circumstances created by the COVID-19 pandemic.

Table 6. General information of the fire safety experts who participated in the survey.

\begin{tabular}{|c|c|c|c|c|c|}
\hline \multirow{2}{*}{ Division } & \multirow{2}{*}{ Responsibilities } & \multicolumn{4}{|c|}{ Work Experience } \\
\hline & & Total & $0 \leq$ years $<10$ & $10 \leq$ years $<19$ & $20 \leq$ years \\
\hline \multirow{3}{*}{ Fire officer } & Fire suppression and first aid & 89 & 51 & 29 & 9 \\
\hline & Fire administration & 28 & 6 & 10 & 12 \\
\hline & Firefighting research & 8 & 1 & 5 & 2 \\
\hline University professor & $\begin{array}{l}\text { Research and education related to } \\
\text { firefighting/disaster prevention }\end{array}$ & 4 & 0 & 2 & 2 \\
\hline Researcher & $\begin{array}{l}\text { Research related to } \\
\text { firefighting/disaster prevention }\end{array}$ & 17 & 3 & 10 & 4 \\
\hline Association & $\begin{array}{l}\text { Activation and education of } \\
\text { firefighting/disaster prevention }\end{array}$ & 19 & 2 & 4 & 13 \\
\hline Industry & $\begin{array}{l}\text { Designing fire extinguishing } \\
\text { facilities }\end{array}$ & 12 & 0 & 4 & 8 \\
\hline \multirow[t]{2}{*}{ Insurance } & $\begin{array}{l}\text { Practical affairs in building fire } \\
\text { insurance }\end{array}$ & 4 & 0 & 3 & 1 \\
\hline & Total & 181 & 63 & 67 & 51 \\
\hline
\end{tabular}

\section{Results}

\subsection{Results of Fire Safety Expert Survey}

The results of the total average score and confidence interval for the preliminary FRI evaluation items are presented in Table 7. In the results of this expert survey, Cronbach's alpha coefficient for fire extraction facilities, construction information, and risk factors were 
calculated as $0.783,0.822$, and 0.792 , respectively, and the reliability was analyzed to be acceptable or higher.

Table 7. Results of total average score and confidence interval of the FRI preliminary evaluation items.

\begin{tabular}{|c|c|c|c|c|c|c|c|}
\hline \multirow{2}{*}{ Category } & \multirow{2}{*}{ Preliminary Evaluation Items } & \multirow{2}{*}{$\mathrm{TA}^{1}$} & \multirow{2}{*}{$\mathrm{SD}^{2}$} & \multirow{2}{*}{$\mathrm{V}^{3}$} & \multicolumn{2}{|c|}{$\mathrm{CI}^{4}$} & \multirow{2}{*}{$\mathrm{CA}^{5}$} \\
\hline & & & & & Upper & Lower & \\
\hline \multirow{7}{*}{$\begin{array}{c}\text { Fire } \\
\text { extinguishing } \\
\text { facilities }\end{array}$} & (1) Outdoor fire extinguisher & 4.06 & 0.82 & 0.67 & 3.94 & 4.17 & \multirow{7}{*}{0.783} \\
\hline & (2) Outdoor fire hydrant & 3.93 & 0.83 & 0.68 & 3.81 & 4.05 & \\
\hline & (3) Fire detection system & 4.13 & 1.00 & 0.99 & 3.99 & 4.28 & \\
\hline & (4) Sprinkler & 4.25 & 0.93 & 0.87 & 4.11 & 4.38 & \\
\hline & (5) Size of the 119 Safety Center & 3.80 & 0.87 & 0.76 & 3.67 & 3.93 & \\
\hline & (6) Distance to 119 Safety Center & 4.06 & 0.83 & 0.69 & 3.94 & 4.18 & \\
\hline & (D) Distance to A\&E & 3.49 & 1.00 & 1.01 & 3.35 & $\begin{array}{l}4.10 \\
3.64\end{array}$ & \\
\hline \multirow{8}{*}{$\begin{array}{l}\text { Construction } \\
\text { information }\end{array}$} & (1) Year of completion & 3.72 & 0.90 & 0.80 & 3.59 & 3.85 & \multirow{8}{*}{0.822} \\
\hline & (2) Building structure & 4.03 & 0.82 & 0.67 & 3.91 & 4.15 & \\
\hline & (3) Principal use of building & 3.67 & 0.92 & 0.84 & 3.54 & 3.81 & \\
\hline & (4) Number of upper ground levels & 3.83 & 0.94 & 0.88 & 3.70 & 3.97 & \\
\hline & (5) Number of lower ground levels & 3.52 & 0.96 & 0.93 & 3.38 & 3.67 & \\
\hline & (6) Gross floor area of building & 3.99 & 0.88 & 0.77 & 3.87 & 4.12 & \\
\hline & (7) Type of building cladding & 4.45 & 0.81 & 0.65 & 4.33 & 4.56 & \\
\hline & (8) Number of regular building occupants & 3.90 & 0.96 & 0.91 & 3.76 & 4.04 & \\
\hline \multirow{5}{*}{ Risk factors } & (1) History of fire incidents & 3.34 & 1.01 & 1.01 & 3.19 & 3.48 & \multirow{5}{*}{0.792} \\
\hline & (2) Illegal alterations & 4.35 & 0.83 & 0.68 & 4.23 & 4.47 & \\
\hline & (3) Illegal parking & 4.20 & 1.02 & 1.04 & 4.05 & 4.35 & \\
\hline & (4) Electrical equipment & 4.19 & 0.82 & 0.68 & 4.07 & 4.31 & \\
\hline & (5) LNG cylinder & 3.82 & 0.87 & 0.75 & 3.69 & 3.94 & \\
\hline
\end{tabular}

${ }^{1}$ TA: Total average; ${ }^{2}$ SD: Standard deviation; ${ }^{3}$ V: Variance; ${ }^{4} \mathrm{CI}$ : Confidence interval of $95 \%$ confidence level

5 CA: Cronbach's alpha coefficient.

The total average of the preliminary FRI evaluation items was in the order of type of building cladding (4.45) > illegal alterations (4.35) > sprinkler (4.25) > illegal parking (4.20) $>$ electrical equipment (4.19) $>$ fire detection system (4.13), etc.

The type of building cladding is because, in the case of combustible cladding materials, there is a high risk of fire spreading to the upper floors and adjacent buildings, which may cause considerable difficulties in fire suppression activities. In addition, commonly used organic insulators have combustion characteristics with spalling failure and high risk of fast fire spread after ignition. Moreover, the fire is highly likely to develop into a large-scale fire when it starts in a closed space. Australia, China, and the UK have recently increased their level of awareness of the fire risks in major buildings in relation to highly flammable exterior cladding panels [35-37].

Illegal alterations mean cases of illegal changes in building use or illegal extensions and lead to the lack of shelter and fire spread. Because small obsolete buildings are more than 30 years old, there are many cases where illegal alterations have been carried out during their use process, and sandwich panels that are simple to install but highly flammable are mainly used for illegal alterations. Moreover, there were many difficulties in directly grasping it because illegal alterations require time-series information to compare before and after alterations.

Sprinklers and fire detection systems are automated fire extinguishing facilities that enable early response in the early stages of fire. This plays a major role in reducing the scale of fire damage in the event of a fire because it can automatically detect the fire and extinguish it early. In addition, obstruction of fire engine access roads due to illegal parking, and electrical equipment items exposed to the outside were also determined to be the main evaluation items.

The results of the average score for the preliminary FRI evaluation items according to the fire safety expert survey are presented in Table 8 and Figure 4. Fire officers assigned high scores to the status of sprinkler installation, distance from a 119 Safety Center, and improvement in illegal parking. It is considered that this result is based on the desire to prevent further spread, which can result in large-scale fires by means of initial fire suppression using fire extinguishing facilities, and then securing prompt access for fire services. Other opinions have emphasized the importance of the appointment of a safety 
manager and regular inspection of fire safety management facilities. University professors specializing in firefighting and disaster prevention emphasized the dangers of outdated electrical equipment, illegal alterations, sprinklers, and illegal parking. It is considered that this result was because aged electrical equipment may increase the risk of fire, and illegal alterations may cause large-scale suffocation incidents in the event of a fire. Researchers from firefighting research institutes, members of the KFSI/KDPA, industry experts in charge of designing fire extinguishing facilities, and staff from fire insurance companies also pointed out similar items as described by the fire officers and university professors as the main evaluation items.

Table 8. Analysis of average score of the FRI preliminary evaluation items.

\begin{tabular}{|c|c|c|c|c|c|c|c|c|}
\hline \multirow{2}{*}{ Category } & \multirow{2}{*}{ Preliminary Evaluation Items } & \multicolumn{7}{|c|}{ Average Score } \\
\hline & & $\mathrm{TA}^{1}$ & $\mathrm{FO}^{2}$ & UP $^{3}$ & $\mathbf{R}^{4}$ & $\mathbf{M}^{5}$ & $\mathrm{IE}^{6}$ & $\mathrm{IC}^{7}$ \\
\hline \multirow{7}{*}{$\begin{array}{c}\text { Fire } \\
\text { extinguishing } \\
\text { facilities }\end{array}$} & (1) Outdoor fire extinguisher & 4.06 & 4.04 & 4.00 & 4.18 & 3.79 & 4.42 & 4.25 \\
\hline & (2) Outdoor fire hydrant & 3.93 & 3.91 & 4.25 & 3.88 & 3.79 & 4.17 & 4.50 \\
\hline & (3) Fire detection system & 4.13 & 4.19 & 4.50 & 4.35 & 2.95 & 4.67 & 5.00 \\
\hline & (4) Sprinkler & 4.25 & 4.30 & 4.50 & 4.47 & 3.16 & 4.75 & 5.00 \\
\hline & (5) Size of the 119 Safety Center & 3.80 & 3.87 & 3.75 & 3.59 & 3.68 & 3.50 & 4.00 \\
\hline & (6) Distance to 119 Safety Center & 4.06 & 4.15 & 4.00 & 3.94 & 3.74 & 3.83 & 4.00 \\
\hline & (D) Distance to A\&E & 3.49 & 3.62 & 3.50 & 3.06 & 2.95 & 3.67 & 3.25 \\
\hline \multirow{8}{*}{$\begin{array}{l}\text { Construction } \\
\text { information }\end{array}$} & (1) Year of completion & 3.72 & 3.82 & 4.00 & 3.76 & 3.21 & 3.58 & 3.00 \\
\hline & (2) Building structure & 4.03 & 4.12 & 3.50 & 4.12 & 3.42 & 3.83 & 5.00 \\
\hline & (3) Principal use of building & 3.67 & 3.78 & 3.50 & 3.53 & 3.32 & 3.83 & 2.50 \\
\hline & (4) Number of upper ground levels & 3.83 & 4.00 & 4.00 & 3.29 & 3.37 & 4.00 & 2.50 \\
\hline & (5) Number of lower ground levels & 3.52 & 3.66 & 3.75 & 3.29 & 3.11 & 3.33 & 2.50 \\
\hline & (6) Gross floor area of building & 3.99 & 4.00 & 3.75 & 4.06 & 3.89 & 3.83 & 4.75 \\
\hline & (7) Type of building cladding & 4.45 & 4.46 & 5.00 & 4.71 & 3.84 & 4.67 & 4.75 \\
\hline & $\begin{array}{l}\text { (8) Number of regular building } \\
\text { occupants }\end{array}$ & 3.90 & 3.98 & 3.25 & 4.06 & 3.68 & 3.67 & 3.00 \\
\hline \multirow{5}{*}{ Risk factors } & (1) History of fire incidents & 3.34 & 3.45 & 3.25 & 3.47 & 2.32 & 3.83 & 2.75 \\
\hline & (2) Illegal alterations & 4.35 & 4.28 & 4.50 & 4.71 & 4.16 & 4.67 & 4.75 \\
\hline & (3) Illegal parking & 4.20 & 4.34 & 4.50 & 4.12 & 3.26 & 4.33 & 4.00 \\
\hline & (4) Electrical equipment & 4.19 & 4.15 & 5.00 & 4.35 & 4.05 & 4.42 & 4.00 \\
\hline & (5) LNG cylinder & 3.82 & 3.84 & 4.00 & 4.06 & 3.53 & 3.83 & 3.25 \\
\hline
\end{tabular}

${ }^{1}$ TA: Total average; ${ }^{2}$ FO: Fire officer; ${ }^{3}$ UP: University professor; ${ }^{4}$ R: Researcher; ${ }^{5}$ M: Member of KSFI/KDPA

${ }^{6}$ IE: Industry expert; ${ }^{7}$ IC: Insurance companies.

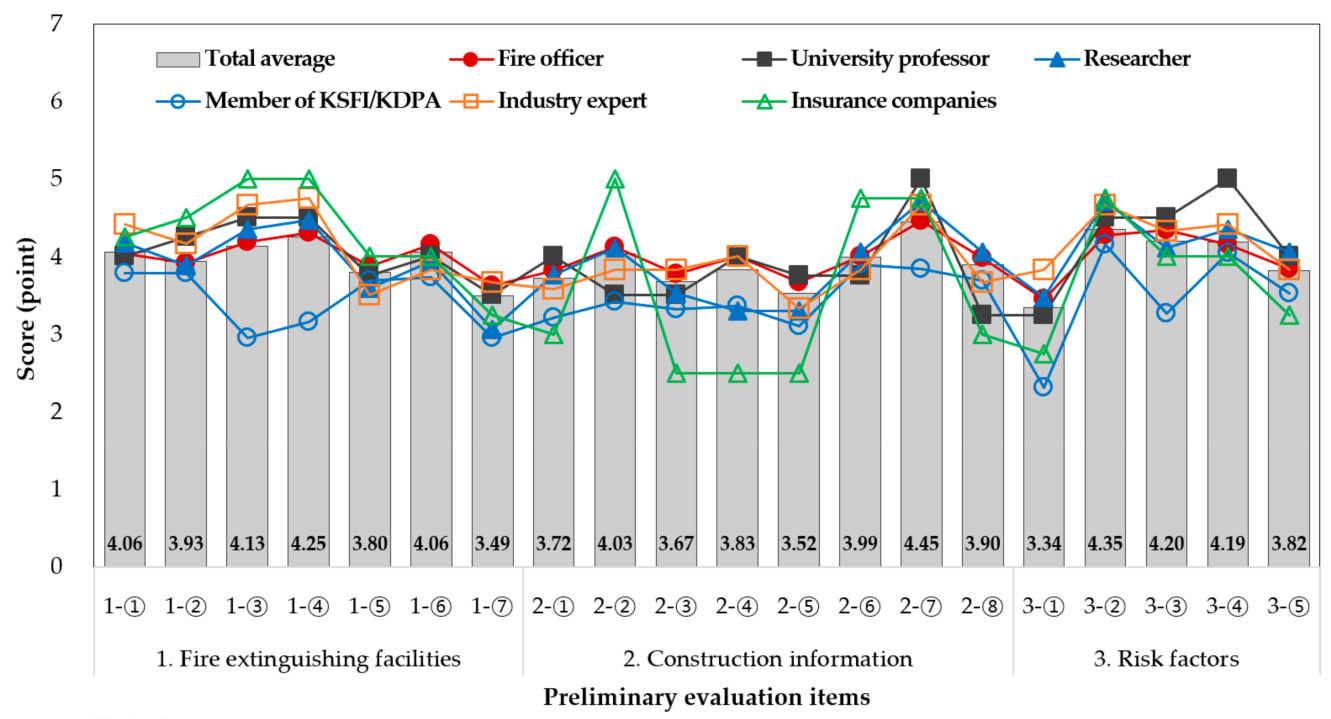

[Index]

1-(1): Outdoor fire extinguisher; 1-(2): Outdoor fire hydrant; 1-(3): Fire detection system; 1-(4): Sprinkler; 1-(5): Size of the 119 Safety Center; 1-(6): Distance to 119 Safety Center; 1-(7): Distance to A\&E; 2-(1): Year of completion; 2-(2): Building structure; 2-(3): Principal use of building; 2-(4): Number of upper ground levels; 2-(5): Number of lower ground levels; 2-(6): Gross floor area of building; 2-(7): Type of building cladding; 2-(8): Number of regular building occupants; 3-(1): History of fire incidents; 3-(2): Illegal alterations; 3-(3): Illegal parking; 3-(4): Electrical equipment; 3-(5): LNG cylinder.

Figure 4. Analysis of the average score of the FRI preliminary evaluation items. 


\subsection{Major Fire Risk Evaluation Items}

Based on the survey results, 12 major evaluation items to concisely assess the fire risk level of dense areas of small obsolete buildings were derived, as outlined in Table 9. The derived main evaluation items were as follows: outdoor fire extinguisher, outdoor fire hydrant, distance to 119 Safety Center, distance to A\&E, year of completion, building structure, gross floor area of building, type of building cladding, illegal alterations, illegal parking, electrical equipment, and LNG cylinders. The selection of these major evaluation items was primarily based on the average value of each evaluation item obtained from the survey results. The lack of a fire detection system and sprinkler in a small obsolete building was excluded from the main evaluation items.

Table 9. FRI major evaluation items.

\begin{tabular}{ll}
\hline \multicolumn{1}{c}{ Category } & \multicolumn{1}{c}{ Major Evaluation Items } \\
\hline \multirow{3}{*}{ Fire extinguishing facilities } & (1) Outdoor fire extinguisher \\
& (2) Outdoor fire hydrant \\
& (3) Distance to 119 Safety Center \\
& (4) Distance to A\&E \\
\hline \multirow{3}{*}{ Construction information } & (1) Year of completion \\
& (2) Building structure \\
& (3) Gross floor area of building \\
Risk factors & (4) Type of building cladding \\
& (1) Illegal alterations \\
& (2) Illegal parking \\
& (3) Electrical equipment \\
\hline
\end{tabular}

\subsection{Utilization Plan of Spatial Information Convergence Technology}

In this study, detailed spatial information convergence technologies were examined and classified into drones, aerial ortho-images, and digital maps. The utilization plan of each detailed technology was developed in relation to the 12 major FRI evaluation items as shown in Table 10.

Table 10. Utilization plan of the spatial information convergence technology.

\begin{tabular}{|c|c|c|c|c|c|}
\hline \multirow[b]{2}{*}{ Category } & \multirow[b]{2}{*}{ Major Evaluation Items } & \multicolumn{3}{|c|}{ Utilization Methods } & \multirow[b]{2}{*}{ Note } \\
\hline & & Drones & $\begin{array}{l}\text { Aerial } \\
\text { Ortho- } \\
\text { Images }\end{array}$ & Digital Map & \\
\hline \multirow{4}{*}{$\begin{array}{c}\text { Fire } \\
\text { extinguishing } \\
\text { facilities }\end{array}$} & (1) Outdoor fire extinguisher & - & - & 0 & - \\
\hline & (2) Outdoor fire hydrant & - & - & O & - \\
\hline & (3) Distance to 119 Safety Center & - & - & 0 & - \\
\hline & (4) Distance to A\&E & - & - & 0 & - \\
\hline \multirow{4}{*}{$\begin{array}{l}\text { Construction } \\
\text { information }\end{array}$} & (1) Year of completion & - & - & - & BL \\
\hline & (2) Building structure & - & - & - & BL \\
\hline & (3) Gross floor area of building & - & - & - & BL \\
\hline & (4) Type of building cladding & O & - & - & - \\
\hline \multirow{4}{*}{ Risk factors } & (1) Illegal alterations & 0 & $\bigcirc$ & - & - \\
\hline & (2) Illegal parking & $\bigcirc$ & $\bigcirc$ & - & - \\
\hline & (3) Electrical equipment & 0 & - & 0 & - \\
\hline & (4) LNG cylinder & $\bigcirc$ & - & 0 & - \\
\hline
\end{tabular}

As a result, among the major evaluation items, outdoor fire extinguishers and outdoor fire hydrants (fire extinguishing facilities) as well as electrical equipment and LNG cylinders (risk factors) could utilize a digital map to determine the status of the location of an old 
building within an effective radius with reference to the GIS coordinates for each facility, as shown in Figure 5. The travel time required from a 119 Safety Center or A\&E (fire extinguishing facilities) to an old building was estimated using the minimum distance calculation based on the location of each facility, as shown in Figure 6.

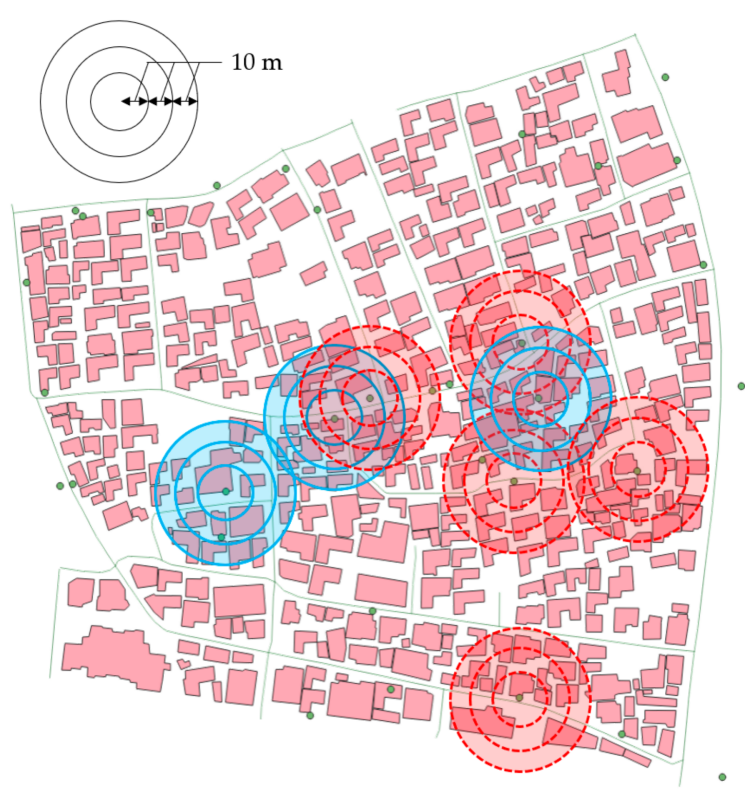

Figure 5. Results of the effective radius with reference to the GIS coordinates for each facility.

It was also found that drone and ortho-image technologies could be utilized for illegal alterations, illegal parking, electrical equipment, and LNG cylinders (risk factors) as well as the type of building cladding (construction information). In particular, it was possible to obtain time-series information of illegal alterations on the rooftop and illegal parking in the fire engine access road during the day, night, weekdays, and weekends based on aerial photography using drones and aerial ortho-images obtained through postprocessing. Cross-validation using digital elevation model data was employed to improve the reading accuracy if the images were difficult to read. The analytical results based on the aerial ortho-images for illegal alterations and illegal parking are shown in Figures 7 and 8, respectively.

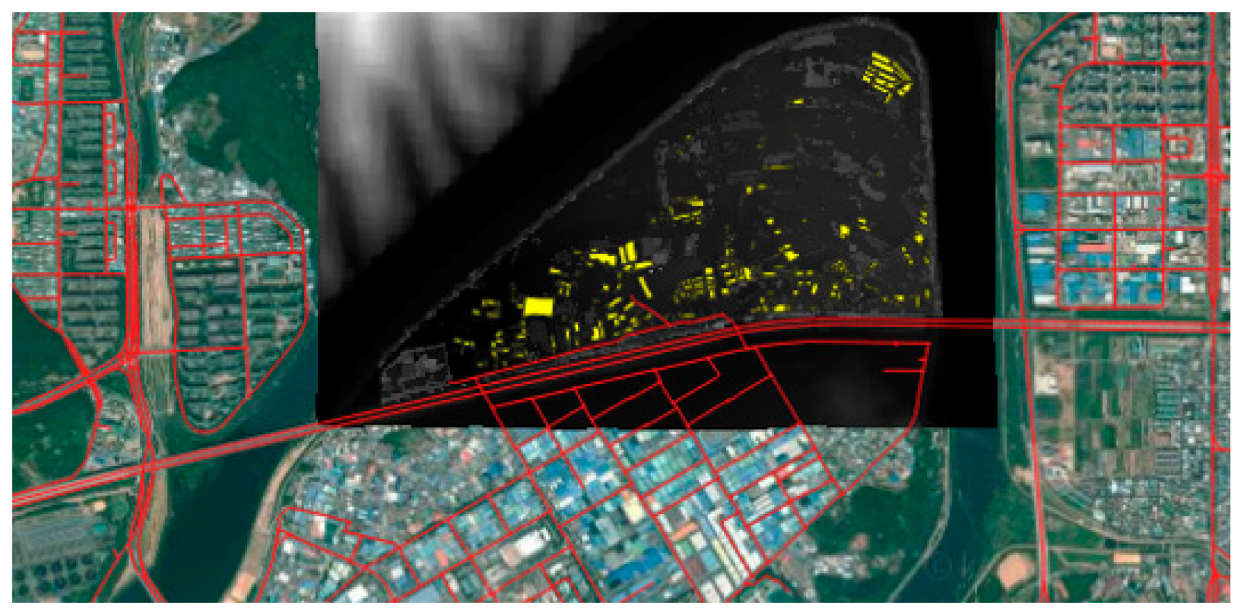

Figure 6. Results of the minimum distance calculation. 


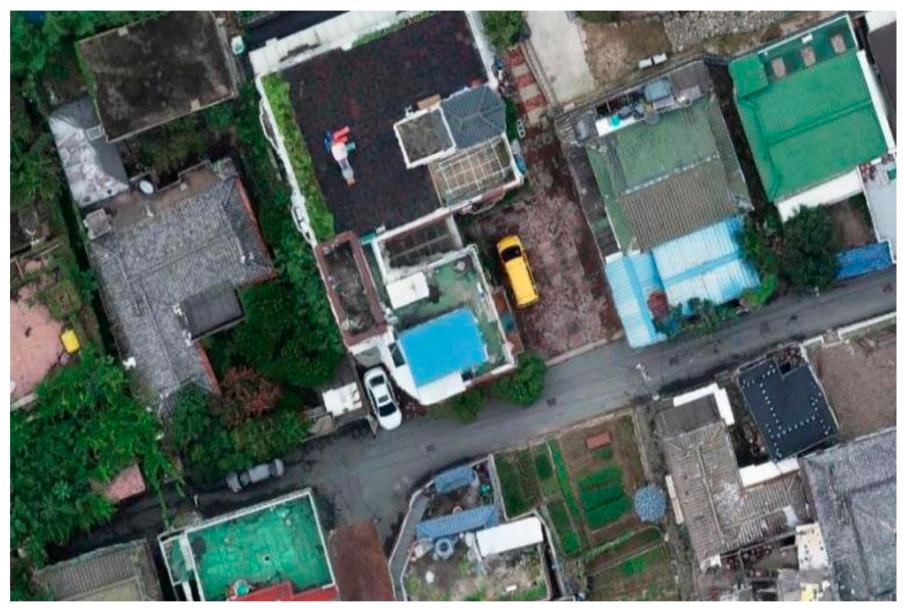

Figure 7. Status of the illegal alterations (rooftop alterations) based on an aerial ortho-image.

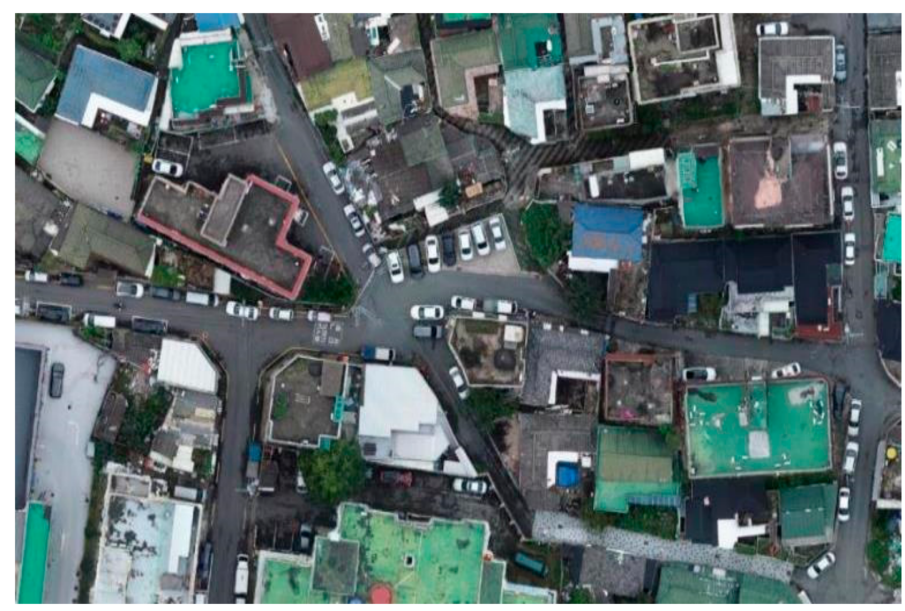

Figure 8. Status of illegal parking based on an aerial ortho-image.

On the other hand, although the year of completion, building structure, and gross floor area of building in the building information category were limits to utilize spatial information convergence technology, which confirmed that information could be collected through the building ledger.

\section{Discussion}

Spatial information convergence technology that links advanced technologies such as drones and GIS enables fast and effective collection and analysis of a large amount of information on fire risk factors, which can contribute to efficient fire management. The significance of this study lies in its derivation of the major evaluation items to determine the fire risk level in dense areas of small obsolete buildings using spatial information convergence technology.

Figure 9 shows an example of the evaluation results of a FRI evaluation platform for dense areas of small obsolete buildings being developed across this whole study. As shown in Figure 9, if the fire risk level of dense areas of small obsolete buildings can be quickly and easily identified by building, it is possible to intensively manage buildings with high fire risk rather than conducting a complete investigation targeting all obsolete buildings. Moreover, it is possible to conduct detailed fire safety inspections of these buildings and expect to reduce the risk of fire effectively. 


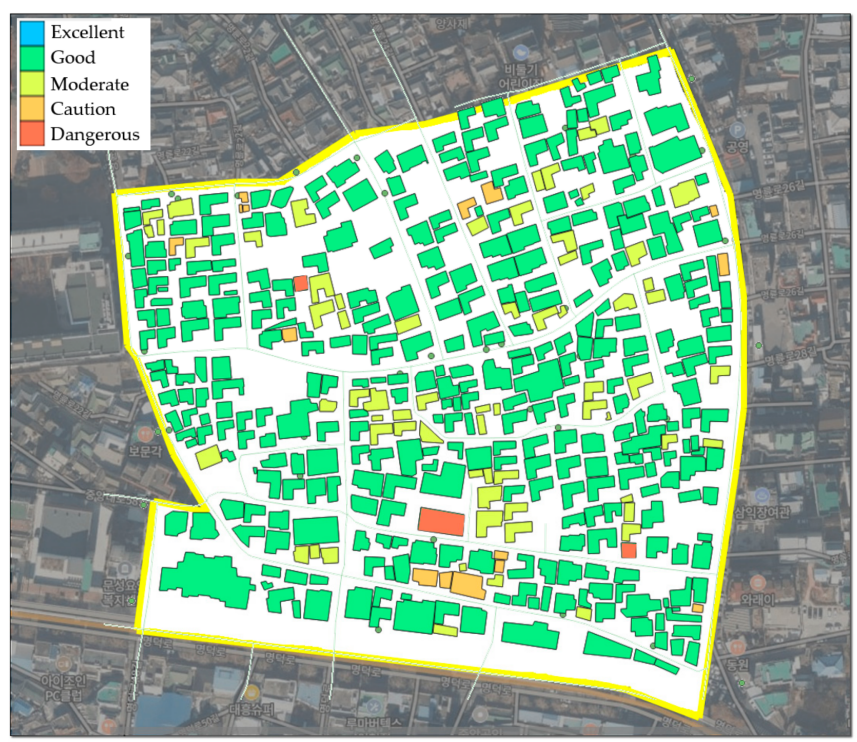

Figure 9. Example of the evaluation result of an FRI evaluation platform for dense areas of small obsolete buildings.

In this study, the major evaluation items utilizing spatial information convergence technology to evaluate the fire risk of small obsolete buildings were analyzed. Through a field survey, investigation of the FRI evaluation items of the U.S. FSES, the Swiss FREM, the Korea FRI, and the publicly used facilities fire risk assessment, and expert pre-reviews, 20 preliminary evaluation items specifically tailored to dense areas of small obsolete buildings were derived. Based on the derived 20 preliminary items, a Likert scale-based importance survey was conducted with a total of 181 fire safety experts including fire officers, university professors, researchers, industry experts, and fire insurers. In the results of this expert survey, Cronbach's alpha coefficients were analyzed to be acceptable or higher. A total of 12 major evaluation items (e.g., outdoor fire extinguisher, distance to 119 Safety Center, building structure, building cladding, illegal alterations, illegal parking, and liquefied natural gas cylinder) were derived and the utilization plan of drones, aerial ortho-images, and digital maps was reviewed by each major evaluation item.

It is considered that the major derived FRI evaluation items for dense areas of small obsolete buildings and the application of spatial information convergence technology used in this study may be utilized as reference data for fire prevention in dense areas of small obsolete buildings and to advance the development of fire safety improvement technology. However, the derivation of appropriate weights between the evaluation items and the development of a specific technology that enables linking between the evaluation items and spatial information convergence technology was limited in this study. Therefore, in the future, the final evaluation model can be completed by calculating the weights between each evaluation item and the evaluation grade index through AHP analysis. The algorithm to calculate the minimum distance for automated evaluation will be optimized, and a FRI evaluation platform, allowing for the attribute, location, and image information to be linked to spatial information convergence technology, will be developed.

\section{Conclusions}

The purpose of this study was to derive major evaluation items to concisely assess the level of fire risk in dense areas of small obsolete buildings and then review a plan to utilize spatial information convergence technology as part of the research on the development of a quick and efficient FRI evaluation platform for dense areas of small obsolete buildings. The main conclusions are outlined as follows. 
1. Based on a field survey, investigation of FRI evaluation items including the U.S. FSES, the Swiss FREM, the Korea FRI, and expert pre-reviews, 20 FRI preliminary evaluation items that are specifically tailored to dense areas of small obsolete buildings were derived.

2. An expert survey based on the Likert scale was conducted with 181 fire safety experts including fire officers, university professors, researchers, industry experts, and fire insurance practitioners. Cronbach's alpha coefficients were analyzed to be acceptable or higher, and the total average of the preliminary FRI evaluation items was in the order of the type of building cladding (4.45) $>$ illegal alterations $(4.35)>$ sprinkler (4.25) > illegal parking (4.20) > electrical equipment (4.19) > fire detection system (4.13), etc.

3. Fire officers assigned high scores to sprinkler installation, distance from 119 Safety Center, and improvement of illegal parking. This result was focused on preventing further spread that could result in a large-scale fire by means of fire suppression using fire extinguishing facilities and securing prompt access for fire services. University professors underlined the risks from outdated electrical equipment and illegal alterations, in addition to sprinkler installation and illegal parking. It is considered that this result was based on aged electrical equipment increasing the fire risk and illegal alterations, causing large-scale suffocation incidents in the event of a fire.

4. Based on the survey results, twelve major fire risk evaluation items for dense areas of small obsolete buildings were derived: outdoor fire extinguishers, outdoor fire hydrants, distance to 119 Safety Center, distance to A\&E, year of completion, building structure, gross floor area of a building, type of building cladding, illegal alterations, illegal parking, electrical equipment, and LNG cylinders.

5. The utilization plan of drones, aerial ortho-images, and digital maps were reviewed as spatial information convergence technology. Drones and ortho-image technologies can be utilized for illegal alterations, illegal parking, electrical equipment, and LNG cylinders as well as the type of building cladding. The effective radius and minimum distance in the digital map can be utilized to evaluate the outdoor fire extinguishers, outdoor fire hydrants, electrical equipment, LNG cylinders, distance to 119 Safety Center, and distance to A\&E.

This study has the significance of deriving major fire risk evaluation items by reflecting on the opinions of various fire experts to evaluate the FRI of dense areas of small obsolete buildings. The utilization of detailed spatial information convergence technologies such as drones and GIS, in relation to the evaluation items, enabled the fast and effective collection and analysis of a large amount of information on the fire risk factors, which can contribute to more efficient fire management. In the future, based on the major evaluation items derived from this study, we plan to develop the FRI evaluation platform for dense areas of small obsolete buildings.

Author Contributions: Conceptualization, S.R. and H.-J.L.; Methodology, J.-R.R. and B.-H.S.; Formal analysis, H.-J.L. and S.-W.P.; Investigation, S.-W.P. and B.-H.S.; Data curation, S.-W.P. and S.R.; Writing-original draft preparation, H.-J.L. and S.R.; Writing-review and editing, J.-R.R., S.-R.R., S.-y.L. and W.-J.P.; Supervision, S.R.; Project administration, S.R. and J.-R.R.; Funding acquisition, S.R. All authors have read and agreed to the published version of the manuscript.

Funding: This research was supported by a grant (21CTAP-C157696-02) from the Technology Advancement Research Program (TARP) funded by the Ministry of Land, Infrastructure, and Transport of the Korean Government.

Institutional Review Board Statement: Not applicable.

Informed Consent Statement: Not applicable.

Data Availability Statement: Not applicable.

Conflicts of Interest: The authors declare no conflict of interest. 


\section{References}

1. World Health Organization. Injuries and Violence: The Facts; World Health Organization: Geneva, Switzerland, 2004.

2. National Fire Agency. 2020 Fire Statistical Yearbook of Korea; Duksung: Sejong, Korea, 2021.

3. Choi, G.; Chang, E.; Kim, S.; Cho, K. Utilization and Excavation Practices of Fire-Fighting Vulnerable Zone Model. J. Korea Spat. Inf. Soc. 2014, 22, 79-87.

4. Kim, E.; Kim, K. A Study on the Construction and Institutionalization of Building Safety Management System; Architecture \& Urban Research Institute: Sejong, Korea, 2019.

5. Kim, Y. Status and Future Tasks of Aged Buildings; NARS Current Issues and Analysis: Seoul, Korea, 2020.

6. Chung, E. A Study on the Development of Risk Index for the Fire Risk Assessment of the Buildings. Ph.D. Thesis, Myongji University, Seoul, Korea, 2008.

7. Koutsomarkos, V.; Rush, D.; Jomaas, G.; Law, A. Tactics, objectives, and choices: Building a fire risk index. Fire Saf. J. 2021, 119, 103241. [CrossRef]

8. Brzezińska, D.; Bryant, P. Risk index method-A tool for building fire safety assessments. Appl. Sci. 2021, 11, 3566. [CrossRef]

9. Radke, D.; Hessler, A.; Ellsworth, D. FireCast: Leveraging Deep Learning to Predict Wildfire Spread. In Proceedings of the Twenty-Eighth International Joint Conference on Artificial Intelligence (IJCAI-19), Macao, China, 10-16 August 2019; pp. 4575-4581.

10. Brzezińska, D.; Bryant, P. Risk Index Method-A Tool for Sustainable, Holistic Building Fire Strategies. Sustainability 2020, 12, 4469. [CrossRef]

11. Fire Risk Assessments. Available online: https:/ / www.fireservice.co.uk/safety/fire-risk-assessment (accessed on 13 August 2021).

12. HM Government. Fire Safety Risk Assessment: Small and Medium Places of Assembly; The Stationery Office: Norwich, UK, 2015.

13. Korean Fire Protection Association. KFPA Fire Risk Index; Korean Fire Protection Association: Seoul, Korea, 2018.

14. Corporate Insurance Risk Management Using Risk Grading (Focused on KFPA Fire Risk Index). Available online: https: / / www.kfpa.or.kr/webzine/202006/sub/disasters4.html (accessed on 13 August 2021).

15. Moon, H. A study on Improvement Method of Self-Inspection System through the Analysis of the Fire Safety Special Investigation. Master's Thesis, University of Seoul, Seoul, Korea, 2019.

16. Kim, Y. A Study on Developing Building Fire Risk Assessment Model and Its Application—Focused on Nonlife Insurer's Risk Management and Underwriting Functions. Ph.D. Thesis, University of Seoul, Seoul, Korea, 2010.

17. Korea Safety Map. Available online: http://www.safemap.go.kr/main/smap.do?flag=2 (accessed on 13 August 2021).

18. Kang, H. Established Smart Disaster Safety Management Response System based on the 4th Industrial Revolution. J. Digit. Contents Soc. 2018, 19, 561-567.

19. Wang, N.; Gao, Y.; Li, C.Y.; Gai, W.M. Integrated agent-based simulation and evacuation risk-assessment model for underground building fire: A case study. J. Build. Eng. 2021, 40, 102609. [CrossRef]

20. Wang, L.; Li, W.; Feng, W.; Yang, R. Fire risk assessment for building operation and maintenance based on BIM technology. Build. Environ. 2021, 205, 108188. [CrossRef]

21. Choi, M.-Y.; Jun, S. Fire Risk Assessment Models Using Statistical Machine Learning and Optimized Risk Indexing. Appl. Sci. 2020, 10, 4199. [CrossRef]

22. Choi, W.; Kim, Y.; Jang, D.; Kim, G.; Jung, Y. A Study on Development of Fire Risk Prediction Model in Manufacturing Facilities Using Artificial Neural Network. J. Korean Soc. Hazard. Mitig. 2017, 17, 161-167. [CrossRef]

23. Twigg, J.; Christie, N.; Haworth, J.; Osuteye, E.; Skarlatidou, A. Improved Methods for Fire Risk Assessment in Low-Income and Informal Settlements. Int. J. Environ. Res. Public Health 2017, 14, 139. [CrossRef]

24. Anderson-Bell, J.; Schillaci, C.; Lipani, A. Predicting non-residential building fire risk using geospatial information and convolutional neural networks. Remote Sens. Appl. Soc. Environ. 2021, 21, 100470. [CrossRef]

25. Stevens, S.; Gibson, L.; Rush, D. Conceptualising a GIS-based risk quantification framework for fire spread in informal settlements: A Cape Town case study. Int. J. Disaster Risk Reduct. 2020, 50, 101736. [CrossRef]

26. Xia, Z.; Li, H.; Chen, Y. An Integrated Spatial Clustering Analysis Method for Identifying Urban Fire Risk Locations in a Network-Constrained Environment: A Case Study in Nanjing, China. ISPRS Int. J. Geo-Inf. 2017, 6, 370. [CrossRef]

27. Masoumi, Z.; van L. Genderen, J.; Maleki, J. Fire Risk Assessment in Dense Urban Areas Using Information Fusion Techniques. ISPRS Int. J. Geo-Inf. 2019, 8, 579. [CrossRef]

28. Nisanci, R. GIS based fire analysis and production of fire-risk maps: The Trabzon experience. Sci. Res. Essays $2010,5,970-977$.

29. Yagoub, M.; Jalil, A. Urban Fire Risk Assessment Using GIS: Case Study on Sharjah, UAE. Int. Geoinform. Res. Dev. J. 2014, 5, 1-8.

30. Xiao, H.; Zhou, Y.; Zhang, H. GIS-based Fire Risk Assessment and Fire Station Site Selection-Taking Dujiangyan City as An Example. In Proceedings of the 2020 IOP Conference Series: Earth and Environmental Science, Taiyuan, China, 16-18 October 2020; Volume 608, p. 012008.

31. Youn, J.; Kim, T. Derivation of Building Fire Safety Assessment Factors for Generating 3D Safety Status Map. J. Korea Acad. Ind. Coop. Soc. 2020, 21, 40-47.

32. Zhao, P.; Zhang, F.; Lin, H.; Xu, S. GIS-Based Forest Fire Risk Model: A Case Study in Laoshan National Forest Park, Nanjing. Remote Sens. 2021, 13, 3704. [CrossRef]

33. Aslani, A.; Hobibi, E. Evaluation of the Risk of Fire by the FRAME Method and Survey of the Effect of Crisis Management Team, on the Level of Fire Risk at a University Hospital During Year 2017. Health Scope 2019, 8, 68151. [CrossRef] 
34. Danzi, E.; Marmo, L. FLAME: A Parametric Fire Risk Assessment Method Supporting Performance Based Approaches. Fire Technol. 2021, 57, 721-765. [CrossRef]

35. Chen, T.B.Y.; Yuen, A.C.Y.; Yeoh, G.H.; Yang, W.; Chan, Q.N. Fire risk assessment of combustible exterior cladding using a collective numerical database. Fire 2019, 2, 11. [CrossRef]

36. Kim, M.; Kim, T.; Yeo, I.H.; Lee, D.; Cho, H.; Kang, K.I. Improvement of standards on fire safety performance of externally insulated high-rise buildings: Focusing on the case in Korea. J. Build. Eng. 2021, 35, 101990. [CrossRef]

37. Osácar, A.; Echeverria Trueba, J.B.; Meacham, B. Evaluation of the Legal Framework for Building Fire Safety Regulations in Spain. Buildings 2021, 11, 51. [CrossRef] 